International Journal of Social Inquiry

Cilt / Volume 12 Sayı / Issue 22019 ss./pp. 567-588

\title{
UNIVERSAL AUTOBIOGRAPHY: SERENADE CHAFIK AND THE LANGUAGE OF HUMAN RIGHTS
}

\section{Emine FİŞEK ${ }^{*}$}

Makale Geliş Tarihi-Received: 16.02.2019

Makale Kabul Tarihi-Accepted: 21.11.2019

DOI: $10.37093 /$ ijsi.659016

\begin{abstract}
Scholars of human rights often note the paradoxical premise of the Universal Declaration of Human Rights (1948): "all human beings are born free and equal in dignity and rights," yet these rights require implementation and monitoring in order to exist. Furthermore, although human rights discourses are premised on a universally recognizable, abstract set of ethical norms, these norms nonetheless need to be enforced as laws by specific states. The period that has witnessed the emergence of human rights as the governing language of emancipatory politics has also witnessed a wealth of autobiographical writing that articulates resistance to oppression and injustice with reference to universal rights. How then do these autobiographical accounts negotiate the paradox of human rights? This article approaches this question through a focus on Egyptian-French feminist Sérénade Chafik's 2003 autobiography Répudiation, which chronicles the author's legal struggle in France to gain custody of her Egyptian-born daughter. The goal is to understand how "rights" are established in literary testimony, to illustrate how the territories of France and Egypt figure in the author's search for a just social order, and to think through how
\end{abstract}

* Assistant Professor, Boğaziçi University, Department of Western Languages and Literatures, İstanbul/Turkey. ORCID: https://orcid.org/0000-0001-7153-2635. emine.fisek@boun.edu.tr 


\section{Emine FİŞEK}

autobiography registers the limitations of a human rights readership community.

Keywords: Sérénade Chafik, Human Rights, Universality, Autobiography, France. 


\section{EVRENSEL OTOBIYYGRAFİ: SERENADE CHAFIK VE İNSAN HAKLARININ DİLI}

\section{ÖZ}

İnsan hakları araştırmacıları sıklıkla İnsan Haklar Evrensel Bildirisi (1948)'nin çelişkili varsayımına dikkat çekerler: "bütün insanlar hür, haysiyet ve haklar bakımından eşit doğarlar," ancak bu hakların var olmaları için uygulamaya konulmaları ve gözetim altında tutulmalarn gerekir. Ayrıca, her ne kadar insan haklarn söylemleri evrensel bir bağlamda tanınabilir, soyut bir takım etik normlarn varsaysa da bu normlarm yine de belirli devletler tarafindan hukuki anlamda yürürlüğe konmaları gerekir. İnsan haklarının özgürlükçü politikalarm ana söylemine dönüştüğ̈̈ dönem aynı zamanda zengin bir otobiyografi yazımına da tanıklık etmiştir. Bu yazımda zulme veya adaletsizliğe karşı duruşların dili eorensel haklara referansla şekillenir. Peki bu otobiyografiler insan haklarının çelişkileri ile nasıl başa çıkarlar? Bu makale bu soruya Mısır doğumlu Fransiz feminist Sérénade Chafik'in 2003 yılında kaleme aldığı ve Mısır'da yaşayan kızının velayeti için Fransa'da yürüttüğ̈̈ çabaları anlattı̆̆̊ otobiyografisi Répudiation'a odaklanarak yaklaşır. Makalenin amaci, "hakları" edebi bir tanıklikta nasıl şekillendiğini, Fransa ve Misır'ın yazarın adaletli bir toplumsal düzen arayışında oynadıkları rollerini, ve otobiyografinin bir insan hakları-bazl okuyucu topluluğunun sinırları ile ilgili farkındalı̆̆ının nasıl dile döküldüğünü anlamaktır.

Anahtar Kelimeler: Sérénade Chafik, İnsan Hakları, Evrensellik, Otobiyografi, Fransa. 


\section{Emine FİŞEK}

\section{INTRODUCTION}

It has become commonplace to state that the figure of the human imagined by the Universal Declaration of Human Rights (1948) is somewhat paradoxical. "All human beings are born free and equal in dignity and rights," the first article of the declaration states. ${ }^{1}$ Yet, this pre-social, abstract vision of humanity requires implementation as well as monitoring in order to exist. In other words, the seemingly innate nature of rights does not relieve them of the need for a social echo chamber, the need for that innate-ness to be recognized by individuals, institutions, communities and states. Not surprisingly, as Jack Donnelly (1989) has noted, references to human rights are most common in contexts where it is in fact their absence that is being illustrated (11). Thus we understand that these monitoring entities learn to distinguish between the presence and absence of rights. In other words, they are able (or ought to be able) to distinguish a rightsbearer from one who is not, a capacity Joseph Slaughter (2007) has referred to as "human rights literacy" (248).

In this article, I wish to understand how the expectation of human rights literacy manifests itself in an autobiographical project, how it influences the author's projection of an anonymous yet specific readership community, and how this project engages with that community when it becomes clear that its own investment in human rights is dwindling. I will focus on Egyptian-French feminist Sérénade Chafik's 2003 autobiography Répudiation: Femme et mère en Egypte: loin des splendeurs pharaoniques, la terrible réalité (Repudiation: woman and mother in Egypt, far from the Pharaonic splendors, the terrible reality), which chronicles the author's legal struggle in France to gain custody of her Egyptian-born daughter, who, if sent to Egypt to live with her father, may be forced to undergo the highly controversial custom of female circumcision. In what follows, I will trace how Chafik engages with notions of rights, whether in institutional or quotidian encounters, how some of these engagements reflect a series of broader paradoxes concerning human rights discourses, as well as how the imagined territories of "France" and "Egypt" figure in her (failed) search for a just social order: a human rights community.

1 "The Universal Declaration of Human Rights: Article 1" available at http://www.un.org/en/documents/udhr/ 
Finally, I will ask: what is the relationship between such a community and cultural products that presume human rights literacy?

\section{HUMAN RIGHTS, INTERNATIONALISM, AUTOBIOGRAPHY}

When it comes to the question of paradox, scholarship on human rights is in decided agreement: on the one hand, contemporary human rights discourse is the product of what Samuel Moyn (2012) has called "a minimalist utopia of anti-politics" (219) that gripped civic imaginaries in the West in the 1970s, producing a vision of betterment that appeared to anchor its certainty in the supra-national space of international law. On the other, it soon became clear that the moral authority of the ethical norms espoused by these discourses required the legal enforcement of these norms as laws by state mechanisms (Asad, 2003). Indeed, long before the emergence of the contemporary global consciousness of human rights, Hannah Arendt (2017) recognized the discrepancy between the idea of rights as premised on membership in a political community and the idea of rights as the automatic accouterment of "human" subjects. Moyn traces the origins of this discrepancy to human rights historiographies that frame the development of human rights discourses in a teleological fashion, connecting contemporary programs to traditions of Enlightenment cosmopolitanism and Early Modern natural right, and ultimately even further back to Christian visions of natural law. Moyn's key argument is that the "rights" traditions of the Enlightenment and Revolutionary eras did not so much transcend states as anchor themselves within them, and that rights were historically always intertwined with spaces of citizenship. The suturing of rights to an international space beyond the nation-state, Moyn argues, is a product of the 1970s and 80s, and connected to "the collapse of prior universalistic schemes, and the construction of human rights as a persuasive alternative to them" (7). Despite their relatively recent origin, however, the international character of contemporary human rights discourses has become an indelible dimension of the forms of recognition that they promise, as well as the forms of passion that this promise incites.

It is perhaps not surprising then that the period that has witnessed the emergence of human rights as the governing language of emancipatory politics has also witnessed a wealth of autobiographical 


\section{Emine FİŞEK}

writing that articulates resistance to oppression and injustice with reference to universal rights and dignity (Schaffer, Smith, 2004). The testimonial form in particular joins literature and the law, suturing them in the project of human rights advocacy and rendering testimony itself into a central element of human rights praxis. These autobiographical accounts document a range of injustices, from the unequal distribution of global wealth and power to the uneven circulation of dignity and recognition. For the purposes of this article, what is important to note about a number of these autobiographies is their simultaneous reliance on and critique of human rights discourses; that is to say that these texts both invest in what Upendra Baxi (2008) calls "the future of human rights," and they document its limitations, the very least of which being its need to translate "human violations" into "human rights violations" (8). In making this distinction, Baxi's concern is with what often remains untranslatable, sometimes even unpronounceable in the realm of human rights discourse: the day-to-day suffering associated with lives that are forced to unfold in spaces of continuous terror. But his decision to underscore the constructedness of "rights violations" pushes us to recognize a basic question: "Why, when, how, and where do narratives become intelligible as stories of human rights?" (Schaffer, Smith 2004: 5).

In what follows, I will show that the form of injustice that Chafik's autobiography descries becomes intelligible as a "human rights violation" precisely because it is articulated from within a context where such intelligibility is freely given, because human rights enjoys a seemingly limitless discursive space and cultural recognition. At the same time, it is precisely because of this surplus of intelligibility that the narrator's experience of the above-named paradox of human rights becomes unbearable. In other words, the cause of Chafik's suffering has already been translated into a human rights violation; the autobiography is a product of Chafik's recognition that the harder task is to re-translate this injury back into the language of civic violation.

\section{CONTRASTING TERRITORIES, HYBRID RIGHTS-TALK}

While the professed goal of Répudiation is to comment on the gender inequality that structures Egyptian society, an inequality for which female circumcision functions as the synecdoche, the book is largely 
an account of Chafik's upbringing in a well to do, left-leaning Francophone Egyptian family. Born in Cairo in 1965, Chafik narrates her childhood and teenage years against the backdrop of an Egypt struggling with Anwar Sadat's liberal reforms, her own life punctured by her family's frequent relocation between France and Egypt. At 19, she settles in Cairo, soon finding herself in two consecutive, untenable marriages. The second of these, to Amr, dissolves beneath the weight of frequent physical abuse, yet when Chafik meets and decides to marry a Frenchman with whom she will move to France, the full extent of the legal hold that Amr has on her becomes clear. Being "repudiated," she must renounce their child, Laila, in order to remarry, which she proceeds to do, maintaining a long-distance relationship with her daughter until the little girl announces, many years later, that her paternal grandmother wishes for her to be circumcised. Thus begins the battle for Laila's custody and the meditation on rights that propels the narrative.

The complicated relationship between rights and citizenship are immediately visible in the opening lines of the book's foreword:

I am thirty-eight years old, I am French and.... repudiated.

The French confuse repudiation and divorce as they might confuse bigamy and infidelity.

Me, I can explain what being a repudiated woman means. In Egypt, this is a woman who doesn't have the same rights as another.

Oh, certainly... she has greater rights than a woman who is simply separated. She can remarry, for example... but in order to do so, she must renounce her children. And it is as such that they took my daughter from me. Because, at twenty-seven years old, repudiated by an Egyptian husband, I wanted to marry a man that I loved.

A Frenchman. (Chafik, 2003: 11)

In the lines that follow, Chafik reveals that her love for the Frenchman, Christophe, eventually took her from Egypt to France, leaving behind her daughter, Laïla. At the time of writing, eleven years after this painful geographic rupture, Chafik begins her narrative with a singular national identity, "I am thirty-eight years 


\section{Emine FİŞEK}

old, I am French," she writes, yet the extent to which her passport can encompass the coordinates of her life is immediately qualified with reference to a legal status originating elsewhere, she is according to Egyptian law "repudiated" and therefore unable to have her daughter accompany her in her geographic and legal transition from Egyptian to French. Over the course of the autobiography, Laila, left-behind, joins a broader set of figures that cannot escort Chafik in her voyage to France. Like Lailla, Egyptian women as a whole, and in the final instance, Egypt itself, cannot be saved and made to undergo a legal transition. While France emerges as the geographic destination of those in love ("I wanted to marry a man that I loved. A Frenchman."), it is also clear that the pursuit of this love comes at the cost of Chafik's legal right to familial life. The absence of custodial rights in other words, is encapsulated in the counter-positioning of romantic love and maternal love. In turn, these emotions are mapped onto the national territories of France and Egypt.

As Chafik's narrative continues however, it is revealed that these territories are not merely national but also conceptual. They embody different sets of values, chief among them the presence/absence of a culture of rights. Chafik's relationship to the French nation, it turns out, far precedes her love of Christophe, and originates instead in her attachment to another man central to her life development:

I had the chance of having a father who is a bit crazy, an artist who, out of love of the French language, gave me the name "Sérénade".

This dreamer wanted me to be a free woman [une femme libre].

At the age of twenty, I also dreamed. I wanted to be a free woman in Egypt. I thought that my milieu and my education would permit me to escape the fate of Muslim women. Except for the Tunisians and the Turks, the majority of Muslim women are fated to be women oppressed by the force of the law.

One day, I understood this, and I left. I chose the nationality of the country that would give me rights. And so I became a French citizen. My father had taught me: France was the homeland of liberty [la patrie de la liberté].

Also, when I learned that my daughter was going to be excised- which is the rule in Egypt- I wasn't fearful. Supported by the laws of the 


\section{Universal Autobiography: Serenade Chafik and the Language of Human Rights}

Republic, I was certain that I would be able to offer her her [emphasis in the original] liberty. (Chafik, 2003: 12)

France is not merely a destination that Chafik associates with the French man whom she loves and marries. "France" encapsulates a promise of liberty that is both territorially bound, and therefore available only to those who become French citizens, and conceptually mobile, universal, articulated from within the Egyptian family into which Chafik is born. This discrepancy resonates with the basic paradox structuring human rights discourses: on the one hand, Chafik references universal precepts that appear to override the circumstances of a particular national polity; on the other, these precepts have little applicability when not joined to the political power of the laws of a nation-state. Thus, when Chafik notes that she "chose the nationality of the country that would give me rights," this act of agency is undertaken with full awareness of human rights' compromised universality. "Rights" are both contingent on the particular national citizenship that is French, and ideally available to all those who desire freedom from oppression, a desire whose governing language has, in the latter half of the twentieth century, been the language of human rights. The term "human" does not enter Chafik's narrative at this stage, it arrives somewhat later. Yet the baseline commonalities that Chafik attributes to a rights-bearing life point precisely to the language encapsulated by the Declaration.

What is Chafik's articulation of "human rights"? First, Chafik wishes to be free from oppression, a freedom guaranteed by French law, yet she wishes to exercise this freedom in Egypt, also: "I wanted to be a free woman in Egypt." Second, trusting in the national laws of the French Republic, Chafik notes that she is certain she will be able to offer her daughter "her" liberty, underlining the fact that becoming rights-bearing is for her a process that takes place not only at the level of the individual, but also through individual exchange. Chafik's certainty depends on the ability of a legal structure (French law) to endow her daughter with rights. Yet she figures herself as the one offering those rights to her daughter, just as her father offered her her French name, the French language and the initial desire to belong to the homeland of liberty, from across another national border. Human rights, in other words, operates as a scene of encounter that takes place not merely between individuals and institutions, but between individuals and at the scale of individual life. In this instance, the 


\section{Emine FİŞEK}

rights sensibility of which Chafik speaks functions as a quasigenealogical heritage, an experience of kinship passed down from one generation to the next.

Chafik's language resonates with what Baxi (2008) calls human rights' "discursivity," that is, the different practices or traditions of "rights-talk" (22) that emerge at the perimeters of official human rights discourses. Not all rights-talk enjoy the same degree of recognition, nor the same attribution of competence, leading Baxi to distinguish between "hegemonic" rights talk, which would include for example the human rights references that emergence in discourses of global governance, structural adjustment and development, and "subaltern" rights-talk, which would include "countervailing" (23) discourses of justice that might introduce a slightly different set of rights norms. Chafik's témoignage is evidence of the vast range of positions that rights-talk can occupy in the continuum that runs from hegemonic discourse to subaltern discourse to, indeed, nondiscursivity, what Baxi calls "the non-discursive order of reality, the materiality of human violation" (24). As the passage above quickly reveals, human rights can be refigured in an everyday "vernacularization" (Moyn, 2012: 219), but this vernacular can evoke both hegemonic and non-hegemonic rights talk: it can identify its speaker as an individual at the mercy of institutional structures, while nonetheless reproducing other discourses of global exclusion. In the passage above, this is evident in Chafik's portrayal of the Muslim world: much like Human Rights, Islam is presented as a force and a legal experience that operates beyond national borders, generating a transnational legal domain wherein "Muslim women" are "fated" to experience oppression in their totality. Here, Chafik's vernacular references to a familial tradition of rights-consciousness sit alongside her use of a very different genre of rights-talk, that is, the discourses of civilizational conflict that have generalized the experiences of Muslim populations (and particularly Muslim women) across the globe, and proved one very powerful strand of Western imperialism in the twenty-first century (Mahmood, Hirschkind: 2002).

However, what is crucial to Chafik's positioning of France and Egypt as oppositional territories, both of which operate as metonyms of broader legal imaginings (Human Rights vs. Islamic Law), is that in the space of the autobiography, this opposition is deconstructed. French law does not ultimately protect Laïla, whose custody a French 


\section{Universal Autobiography: Serenade Chafik and the Language of Human Rights}

court grants to her father. In doing so, it deprives Chafik of her own ability to offer her daughter her liberty. And "France," a territory and an idea that is woven into the most intimate dimensions of Chafik's domestic life, in fact destroys any possibility of her maintaining a viable familial life, anywhere in the world. It is this abandonment, ordained at the level of national rights yet emotionally experienced at the level of universal, human rights, that initiates a témoignage, an autobiographical account.

While there is a direct correlation between the act of self-narration and the redemptive social recognition of which this act is assumed to be the vehicle, Chafik's arrival at the scene of writing carries a number of other traces as well. Referencing the "French police" and "French prosecutor" that take her daughter away, Chafik notes:

This is why I wanted to write this book.

In the name of Muslim women reduced to silence.

In the name of women immigrants that nobody hears.

I am going to tell you about my Egypt. [emphasis in the original]

The French know Nefertiti and Cleopatra, certainly, but they are unaware of the situation of some thirty million Egyptians who are quite alive.

In the country of the pyramids, the dead retain still the unfortunate habit of taking the place of the living.

And so let me restore the balance... (Chafik, 2003: 13)

The precise addressee of Répudiation shifts over the course of these brief statements. Initially, the writing stems from a need to explicate the legal barriers with which Chafik has come into contact in France. Yet the silent chorus in whose name the writing happens is composed of individuals whose life conditions, as she establishes earlier, could not be more distant from French law, namely the monolithic category of "Muslim women." As the foreword ends, the addressee of the 


\section{Emine FİŞEK}

writing is once again established as the Nefertiti and Cleopatra-savvy French. Unlike these ancient queens, Chafik writes, millions of Egyptian women are "quite alive." In the French imagination however, the Pharaonic dead are the ones to walk the streets of Egypt. This ambiguity of address significant for more than one reason. On the one hand, it demonstrates the variety of rights-talk that coalesces in the space of the autobiography. On the other, it connects the concerns of "Muslim women" and an ill-informed French readership through the figure of "women immigrants," thus positing a natural continuity between "Muslim women" and "women immigrants." This rhetorical move is not arbitrary, and is indicative of the broader

Our understanding of how Chafik stages her autobiography could emphasize a series of resonances with the broader category of "becoming rights-bearing" literature, autobiographies such as Somaliborn Dutch author Ayaan Hirsi Ali's Infidel and Turkish-German Necla Kelek's The Foreign Bride that map the narrator's acquisition of rights onto a migratory path angled away from Muslim-majority countries and towards Euro-America. That Chafik reaches out towards the "Muslim women" she had left behind could be understood as an efficacious way of evoking an imaginary of gendered pain in twenty-first century France. Indeed, in 2003, when Répudiation is published, Islam in general and female circumcision in particular occupy specific positions in French public discourse. The stigmatization of Islamic ritual practices can be traced back to the beginnings of the "the first "Islamic headscarf" affair" (Geisser, 2003: 17) in 1989, when three Muslim girls in Creil insisted on wearing their headscarves in their state school, a demand that launched a national debate on Islam, the Republic's core principle of laïcité, and the role of the state school in the defense of secular national values. This debate eventually resulted in a 2004 law banning the display of "conspicuous signs" (Hargreaves, 2007: 114) of religiosity in public schools, widely interpreted as a discriminatory measure targeting Muslim communities. In many ways, the extended headscarf saga provided the backdrop to a set of broader debates regarding the Republic's failure to integrate a multicultural polity: it would join sensationalized media discoveries of polygamous family arrangements and clandestine female circumcision networks, and coupled with the 


\section{Universal Autobiography: Serenade Chafik and the Language of Human Rights}

seeming urgency of a post-9/11 era, generated an image of France's (predominantly Muslim) immigrant communities as living lives incompatible with French values.

The development of female circumcision discourses occupies the same time frame yet extends beyond continental Europe to the United States, where applications for refugee status premised on fear of undergoing the practice routinely draw media attention and have come to exemplify "the prism through which all African women are viewed, a sign of their 'otherness' " (Brière, 2005: 166). Françoise Lionnet (2005) notes that in France, a 1981 law criminalizing violence against minors has been referenced multiple times to charge immigrant parents for injuring their daughters, noting that such judicial cases, oriented towards the punishment of individual intentionality, often fail to address the collective identity on behalf of which certain ritualized procedures can be undertaken (99). Length restrictions do not permit a broader comment here on female circumcision, but it is crucial to note that the custom has occasioned passionate debate between what are often dichotomized as "relativist and universalist paradigms" (Abusharaf, 2000: 155), approaches characterized by culture-specific understandings of human dignity and flourishing on the one hand, and the positioning of all such practices as a menace to the right to bodily dignity, on the other. Indeed, the corporeal dimensions of the practice stand at the core of a number of Western feminist critiques of female circumcision, with a particular focus on the ritual's perceived disruption of the link between self-determination and sexuality. While references to the physical integrity of the body partake of a far lengthier lineage of rights discourses, one which Lynn Hunt (2007) has traced to the decades preceding the Declaration of the Rights of Man and Citizen, the ritual's assumed effect on the individual's ability to experience sexual pleasure has a more recent origin in 1970s feminism (Korieh, 2005: 113-114).

This brief background supplies one important framework for understanding Chafik's desire to speak on behalf of "Muslim women" and "women immigrants": these references are uttered in a context where they will inevitably evoke a citational chain stretching from female circumcision to the "Islamic headscarf" to broader discourses of immigration and integration. Such a framing positions Chafik's narrative as one in a series of autobiographical testimonies buttressing 


\section{Emine FİŞEK}

contemporary French discourses on Islam's ills. As such, Répudiation functions as exemplary of a literary testimony that is meant to 1) right the fruitlessness of Chafik's other testimony (her unsuccessful legal demonstration of her daughter's right to stay in France), and 2) establish testimony itself as fundamental to human rights activism and the generation of a human rights community. In the process, Répudiation also illustrates how the form of a rights-claiming narrative is shaped by the context in which it is enunciated, and by the boundaries of the public sphere within and against which the narrator wishes to position themselves. "At any historical moment," Schaffer and Smith (2004) write, "only certain stories are tellable and intelligible to a broader audience" (32).

At the same time, however, this frame is only one of the contexts through which to evaluate Répudiation's dynamics. What is telling about the autobiography is its inability to fully locate itself within the public sphere in question, as well as to claim an identity for its narrator. The following excerpt provides us with an alternative rendering of the relationship between the individual, the law and literature:

"What kind of happiness do you foresee for me? Paint me the picture of your happy Antigone. What are the unimportant little sins that I shall have to commit before I am allowed to sink my teeth into life and tear happiness from it? Tell me: to whom shall I have to lie? Upon whom shall I have to fawn? To whom must I sell myself? Whom do you want me to leave dying, while I turn away my eyes?"2

My theater teacher said that Anouilh's piece seemed to have been written for me. Among all of his apprentice actors, I wasn't the most beautiful, but I was the best at incarnating an obsession with purity,

2 In translating this excerpt from Chafik's text, I have used the corresponding quote from the Lewis Galantière translation of Anouilh's play. Please see the References section for full bibliographic details. Anouilh's (2008) original reads: “Que sera-t-il, mon bonheur? Quelle femme heureuse deviendra-t-elle la petite Antigone? Quelles pauvretés faudra-t-il qu'elle fasse elle aussi, jour après jour, pour arracher avec ses dents son petit lambeau de bonheur? Dites, à qui devra-t-elle mentir, à qui sourire, à qui se vendre ? Qui devra-t-elle laisser mourir en détournant le regard?" 


\section{Universal Autobiography: Serenade Chafik and the Language of Human Rights}

the search for an absolute justice. For our play, he had given the role to me. (Chafik, 2003: 149)

Narrating her turbulent teenage years in Paris, Chafik remembers having been picked by her theater instructor to perform in the title role of French playwright Jean Anouilh's Antigone (1944). Anouilh's play is based on Sophocles's Antigone (441 BC), which takes place in the aftermath of Thebes' civil war. Brothers Eteocles and Polyneices have fought and perished on opposing sides, and Creon, the Theban King, mandates that whereas the former will receive full burial rites, the latter's body will be left to rot. Unable to bear Creon's decree, Antigone vows to bury Polyneices. Often construed as an allegory of dissent under the German occupation, Anouilh's re-writing undermines Sophocles's core tension between legal mandates and a set of moral principles that are imagined to precede an individual's socialization into any legal structure. The original Antigone's tragic path is shaped by the dialectical relationship between prophecy and agency; Anouilh's heroine, however, is set on a tranquil, friction-less road to self-destruction. In the excerpt quoted by Chafik, she is responding to Creon's suggestion that she abandon her quest for her brother Polyneices' proper burial, instead plunging herself into the small contentments of life. In a series of questions, Antigone imagines a life wherein she will repeatedly have to turn her gaze away from a dying body. The "purity" and "absolute justice" to which Chafik refers are configured as principles that precede positive law. The resolve with which Antigone approaches her brother's death rites is laid like an interpretive frame onto Chafik's own acts of resistance and disobedience, directed first at her parents, then her successive husbands, and finally her successive states.

Given Répudiation's heartbreaking legal finale, we might assume that Antigone's obligations vis-à-vis Polyneices are meant to parallel Chafik's obligations vis-à-vis Laïla, commitments that are imagined here to precede man-made legal structures. It is perhaps this parallel that results in a narrative whose addressee shifts from "Muslim women" to the French citizens ignorant of their struggles. In other words, it is difficult to determine what Nancy Fraser (2009) would refer to as "the "who" of [absolute] justice" (24), the frame within which its conception of fairness will be made to make sense, if indeed this conception exceeds the kinds of moral commitments recognized by the laws governing a particular national polity. Antigone is thus a 


\section{Emine FİŞEK}

particularly poignant choice for Chafik for she is, as Slaughter (2007) notes, the "classical literary heroine" of natural law: "transcendental precepts that presumably go without saying" (14), such as the protection of one's kin. In turn, the language of human rights is responsible for grafting the self-evidence ("presumably go without saying") of natural law onto the vehicles of positive law. However, the addressee towards whom the author must direct the declaration of this self-evidence is less clear, for who can serve as an appropriate human rights membership community? Individuals who have suffered? Or individuals who are obliged by their moral training to

\section{UNIVERSAL PRINCIPLES, PARTICULAR POLITICS}

At this juncture, let's return to an ill fit traced earlier: the relationship between supra-national principles such as human rights and their ratification in national laws. As the narrative hurtles towards Chafik's legal loss, the voice of her lawyer threads its way in at various points to assure his client of the infallibility of French law:

France cannot recognize discriminatory laws, French law cannot depend on a customary law, an incarnation of Islamic law, which systematically accords prerogatives to the father, affirmed my lawyer. This is a social order that is contrary to the universalist principles of the French Republic. (Chafik, 2003: 318)

It soon turns out however that "universalist principles" cannot be divorced from political structures, as France and Egypt have signed a convention of judicial cooperation on civil matters, a convention cited by Chafik's ex-husband in his demand for custody. "If diplomacy gets mixed up in this," foreshadows her lawyer, "...everything will get complicated" (321). And complications do ensue. Laïla's case is symbolically mapped onto then-Egyptian President Hosni Moubarak's visit with French President Jacques Chirac: its potentially Egypt-friendly outcome is represented as evidence of the two countries' ever tightening commercial relations. In the Egyptian press, Chafik is narrated as a "kidnapper" (322) who wishes to attack the 


\section{Universal Autobiography: Serenade Chafik and the Language of Human Rights}

Egyptian state. "Universalist principles," in other words, are endowed with a wide range of meanings. For the case's Egyptian followers, they serve as a reincarnation of colonial attitudes designed to humiliate the post-colonial nation, far from comprising a just global society. In France, conversely, the "universality" of the vision of justice encapsulated by French law becomes a matter of discussion between civic groups. The numerous non-governmental organizations with which Chafik works reference the figure of the child in international, universal conventions to critique the French state's particularistic international politics. Ultimately, however, Chafik cannot succeed in re-translating her cause from a universal, human rights violation to a civil violation for which her new national context is responsible. The autobiography ends with Chafik's extensive organizational and individual thank you list, a list which functions not only as a who's who of early twenty-first century French feminist, anti-racist and pro-human rights aid networks, but in a sense exempts civil society from the failure of French law.

Talal Asad (2003) links this problematic to the particular kind of "human" imagined by human rights discourses: "Human rights, including the moral rules that bind humans universally, are intrinsic to all persons irrespective of their "cultural" make-up. Yet the identification and application of human rights law has no meaning independent of the judicial institutions that belong to individual nation-states... and therefore of the individual's civil status as a political subject" (129). In other words, the "universe" is a realm to which one turns precisely when one's status as citizen is either entirely lost or when the rights associated with citizenship lead to an unjust outcome. Hannah Arendt's (2017) seminal comments on the forms of stateless-ness that followed the First and Second World Wars resonate with this insight: whereas human rights is understood to be irreducible to the law, Arendt notes that stateless communities in the interwar era were quick to recognize that there were few authorities to whom they could address themselves with "the abstract nakedness of being human" (389). Chafik's narrative is not about statelessness, but it is exemplary of an autobiography that is forced to address itself to an abstract, universal community.

Répudiation then is premised on the notion that témoignage is the genre correlate of the universe, that it can call forth a human rights readership community able to recognize its own "know-how to 


\section{Emine FİŞEK}

perform a repertoire of significant actions before others who possess similar knowledge" (7), to borrow Vincent Farenga's (2006) definition of democratic citizenship. Yet like almost all human rights advocacy, the writing is undertaken in the aftermath of the rights violation in question, after the performative potential of these significant actions have already been extinguished. In Chafik's autobiography, therefore, human rights literacy does not so much establish a human rights community as announce its passing.

\section{CONCLUSION}

584

IJSI 12/2

When viewed from the vantage point of the early twenty-first century, "the use of human stories for human rights advocacy" (Hunt Botting, 2016: 211) appears to draw on a lengthy and generically varied genealogy. Eighteenth century epistolary novels expand readers' moral imaginations in such a way as to lay the groundwork for later rights sensibilities (Hunt, 2007). Similarly, the era's growing tradition of autobiographical writing views the genre as a moral platform for stressing women's human rights (Hunt Botting 2016). Meanwhile, the modern Bildungsroman remains "the predominant formal literary technology in which social outsiders narrate affirmative claims for inclusion in a regime of rights and responsibilities (Slaughter, 2007: 27). Biography, in other words, whether in its fictional or its nonfictional variety, has been central to the political and cultural discourses of human rights. "Precisely because the discourse of human rights is addressed to the human individual as a person," Glenn Mitoma (2010) argues, "the narrative of the individual person is a critical component in the scholarly engagement with human rights" (223).

Chafik's témoignage is evidence that the precise work that this "critical component" can perform in the diffusion of a human rights sensibility remains unpredictable, subject to change and fluctuation. Répudiation, like the Bildugsromane studied by Slaughter, "can both articulate narrative claims for inclusion in the normative rights regime and criticize these norms and their inegalitarian implementation by demonstrating the discrepancy between their universalist rhetoric and reality" (28). Répudiation, however, does not merely point to a discrepancy, although the paradoxes outlined above place it in ready conversation with a variety of post-colonial Bildungsromane. Rather, Répudiation is premised on the assumption that témoignage exists in the 
Universal Autobiography: Serenade Chafik and the Language of Human Rights

fraught, limited space between public exposure and official indifference, between international law and state sovereignty. As such, Chafik's aptly titled final chapter, "Who will give me justice?" does not seek a justice provider but perhaps the shared recognition that at times, this question pursues an impossible "who." Témoignage, in this instance, cannot provide the "who," it can merely generate a community that snaps into place upon recognizing the fact that it cannot quite be one, having arrived too late at the scene of reading. 


\section{Emine FİŞEK}

\section{REFERENCES}

Abusharaf, Rogaia Mustafa (2000). "Revisiting Feminist Discourses on Infibulation: Responses from Sudanese Feminists". Shell-Duncan, Bettina; Hernlund, Ylva (Eds.), Female "Circumcision" in Africa: Culture, Controversy, and Change, Boulder: Lynne Rienner Publishers, 151-166.

Anouilh, Jean (1958). Jean Anouilh: Five Plays. Lewis Galantière (Trs.). New York: A Mermaid Dramabook.

Anouilh, Jean (2008). Antigone. Paris: Table Ronde.

Arendt, Hannah (2017). The Origins of Totalitarianism. UK: Penguin Books.

Asad, Talal (2003). Formations of the Secular: Christianity, Islam, Modernity. Stanford: Stanford University Press.

Baxi, Upendra (2008). The Future of Human Rights. New Delhi and Oxford: Oxford University Press.

Brière, Eloïse A. (2005). "Confronting the Western Gaze". Nnaemeka, Obioma (Ed.), Female Circumcision and the Politics of Knowledge: African Women in Imperialist Discourses, Westport: Praeger, 165-183.

Chafik, Sérénade (2003). Répudiation: Femme et mère en Egypte: loin des splendeurs pharaoniques, la terrible réalité. Neuilly-sur-Seine: Michel Lafon.

Donnelly, Jack (1989). Universal Human Rights in Theory and Practice. Ithaca: Cornell University Press.

Fraser, Nancy (2009). Scales of Justice: Reimagining Political Space in a Globalizing World. New York: Columbia University Press.

Geisser, Vincent (2003). La nouvelle Islamophobie. Paris: La Découverte.

Hargreaves, Alec G. (2007). Multi-ethnic France: Immigration, Politics, Culture and Society. New York: Routledge.

Hirschkind, Charles, and Saba Mahmood (2002). "Feminism, the Taliban, and Politics of Counter-Insurgency". Anthropological Quarterly, 75(2), 339-354.

Hunt, Lynn (2007). Inventing Human Rights: A History. New York: W.W. Norton and Company.

Hunt Botting, Eileen (2016). Wollstonecraft, Mill, and Women's Human Rights. New Haven and London: Yale University Press.

Korieh, Chima (2005). "“Other" Bodies: Western Feminism, Race, and Representation in Female Circumcision Discourse". Nnaemeka, Obioma (Ed.), Female Circumcision and the Politics of Knowledge: African Women in Imperialist Discourses, Westport: Praeger, 111-135. 


\section{Universal Autobiography: Serenade Chafik and the Language of Human Rights}

Lionnet, Françoise (2005). “Women's Rights, Bodies and Identities: The Limits of Universalism and the Legal Debate around Excision in France". Nnaemeka, Obioma (Ed.), Female Circumcision and the Politics of Knowledge: African Women in Imperialist Discourses, Westport: Praeger, 97-111.

Mitoma, Glenn (2010). "Charles H. Malik and Human Rights: Notes on a Biography". Biography, 33(1): 222-241.

Moyn, Samuel (2012). The Last Utopia: Human Rights in History. Cambridge: Belknap Press of Harvard University.

Schaffer, Kay, and Sidonie Smith (2004). Human Rights and Narrated Lives: The Ethics of Recognition. Basingstoke: Palgrave Macmillan.

Slaughter, Joseph (2007). Human Rights Inc.: The World Novel, Narrative Form and International Law. New York: Fordham University Press. 


\section{Emine FİŞEK}

\section{ÖZET}

İnsan hakları araştırmacıları evrensel insan hakları söylemlerinin çelişkileri konusunda genellikle hemfikirdirler. Insan Hakları Evrensel Bildirisi (1948), "bütün insanlar hür, haysiyet ve haklar bakımından eşit doğarlar" der, ancak bu soyut insanlık tasavvurunun bir gerçekliğe kavuşması için bireyler, topluluklar, kurumlar ve devletler tarafından tanınması gerekir. Başka bir deyişle, insan haklarının "doğuştan" var olmaları bu hakların belirli devletlerin hukuki sistemleri tarafından özümsenmeye ve korunmaya ihtiyaç duydukları gerçeğini ortadan kaldırmaz. Jack Donnelly'nin (1989) de not ettiği üzere, insan haklarına yapılan göndermeler sıklıkla bu hakların yokluğunun altını çizmek için yapılır ve insan hakları söylemleri kişilere ve masa nasıl islediğini anlamaktır. Kay Schaffer ve Sidonie Smith'e (2004) göre insan hakları söylemlerinin küresel egemenlik elde ettiği dönem aynı zamanda otobiyografi, an ve tanıklık adları altında incelediğimiz edebi türlerin de son derece zenginleştiği ve sayılarının arttığı bir dönemdir. Bu metinler ekonomik eşitsizlikten kültürel tanınmazlı̆̆a kadar bir çok farklı adaletsizliği belgelerler ve bu belgeleme sürecinde evrensel hak ve haysiyet söylemlerine referansla kendi etik duruşlarını sergilerler. İnsan hakları söylemlerini yüceltmekle beraber bu metinler ayn zamanda bu söylemlerin çelişkilerine de dikkat çekerler: örneğin bir hak ihlalinin bir "insanlık" hakkının ihlali olarak tanınması için belli şekillerde çerçevelenmesi, belli "insanlık" imgelerini anımsatması gerekir. Upendra Baxi'ye (2008) göre bazı adaletsizlikler insan hayatını ve refahını o kadar derinden etkiler ki bu tecrübeleri "hak ihlali" diline çevirmek zorlaşır. Aynı şekilde, bazen insan hakları söylemleri çerçevesinde geliştirilen hak taleplerini belirli ulusdevletlerin hukuki mekanizmalarını faaliyete geçirecek şekilde biçimlendirmek yine bir çeviri gerektirir.

Mısır doğumlu Fransız feminist Sérénade Chafik'in 2003 yılında kaleme aldığ1 ve Mısır'da yaşayan kızının velayeti için Fransa'da yürüttüğü çabaları anlattığ1 otobiyografisi Répudiation okuyucusunun "insan hakları okur yazarlığını" varsayar. Ancak Chafik'in belgelediği hukuki süreçte Fransız devletinin kanunları Chafik'in ve kızının "insan" haklarını korumaz, ve insan hakları söylemleri ve ulusal kanunlar arasındaki mesafeyi ortaya koyar. Répudiation bu anlamda önemli bir metindir, çünkü bir yandan adalet talebini insan hakları söylemlerine referansla kurgular, diğer taraftan bu kurgunun kısıtlamalarını gözler önüne serer. Bu makalenin amacı, Répudiation'dan yola çıkarak "hakların" edebi bir tanıklıkta nasıl şekillendiğini, Fransa ve Mısır'ın yazarın adaletli bir toplumsal düzen arayışında oynadıkları rollerini, ve otobiyografinin bir "insan hakları okur yazarları" topluluğunun sınırları ile ilgili farkındalığını nasıl dile getirdiğini irdelemektir. 